UDC $576.31 ; 578.23$

\title{
The accumulation of the basic domain of HIV-1 Tat protein in the nuclei and the nucleoli is different from the accumulation of full-length Tat proteins
}

\author{
Y. R. Musinova ${ }^{1,2}$, E. V. Sheval ${ }^{1,2}$ \\ ${ }^{1}$ A. N. Belozersky Institute of Physico-Chemical Biology, \\ M. V. Lomonosov Moscow State University \\ Leninskie gory, house 1, building 40, Moscow, Russian Federation, 119992 \\ ${ }^{2}$ LIA 1066 French-Russian Joint Cancer Research Laboratory \\ Villejuif, France-Moscow, Russian Federation \\ evsheval@gmail.com
}

\begin{abstract}
Aim. Protein fragments coding for nuclear (NLS) and/or nucleolar (NoLS) localization signals are often used for the investigation of the mechanisms of protein accumulation inside the nuclei and the nucleoli, but it is possible that accumulation mechanisms in full-length proteins will be different. Methods. Here, we compared the nuclear and nucleolar accumulation of HIV-1 Tat protein and its basic domain containing both NLS and NoLS. Results. The pattern of accumulation of the basic domain of HIV-1 Tat protein in the nuclei and the nucleoli is different from that of full-length Tat proteins: the basic domain is accumulated weaker inside the nuclei, but stronger in the nucleoli as compared to the full-length protein. Conclusion. The molecular mechanism of nuclear and nucleolar accumulation of full-length Tat protein might be different from that of the Tat protein fragments.
\end{abstract}

Ke y w o r d s: nucleus, nucleolus, NLS, NoLS, HIV-1 Tat.

\section{Introduction}

The human immunodeficiency virus-1 (HIV-1) produces a small transcriptional activator protein known as a trans-activator of transcription (Tat) which regulates the transcription of viral genes $[1,2]$ and modulates cellular processes by the interaction with different cellular structures, in particular, inside the cell nucleus [3]. The data concerning intranuclear localization of Tat protein are controversial. Tat protein expressed in animal cells is accumulated inside the nucleoli $[4,5]$, but, in stably transfected Jurkat cell, Tat protein was localized in the nucleoplasm [6]. It is possible that different localization depends on the nuclear concentration of Tat. Indeed, in stably transfected HeLa cells, Tat-GFP expressed at a low level was lo- calized only in the nucleoplasm, whereas its overexpression resulted in the nucleolar accumulation [7].

The mechanisms of Tat protein accumulation in the nuclei and in the nucleoli are poorly understood. The cell nucleus contains a large number of substructures (nuclear bodies), within which various processes associated with the functioning of the genome are compartmentalized [8]. It was shown that the nuclear accumulation might depend on the presence of the short sequences in the protein, known as nuclear localization signals (NLSs) [9]. The nucleolar accumulation might be determined by the presence of nucleolar localization signals (NoLSs) [10]. The majority of experimental data concerning the mechanisms of Tat accumulation in the nucleus and the nucleolus are obtained using the chimeric pro-

(C) 2015 Y. R. Musinova et al.; Published by the Institute of Molecular Biology and Genetics, NAS of Ukraine on behalf of Biopolymers and Cell. This is an Open Access article distributed under the terms of the Creative Commons Attribution License (http://creativecommons.org/licenses/by/4.0/), which permits unrestricted reuse, distribution, and reproduction in any medium, provided the original work is properly cited 
The accumulation of the basic domain of HIV-1 Tat protein in the nuclei and the nucleoli is different from the accumulation

teins, which consist of the studied sequence and the marker protein (e.g., EGFP). It is possible that accumulation mechanisms in the full-length proteins will be different. In the present work, we have demonstrated that the pattern of accumulation of Tat protein in the nucleus and the nucleolus is different from that of its basic domain although this domain codes both NLS and NoLS.

\section{Materials and Methods}

To construct Tat-EGFP and EGFP-Tat, the pGST-Tat 1 86R plasmid obtained through the NIH AIDS Reagent Program, Division of AIDS, NIAID, NIH from Dr. Andrew Rice [11] was used. Full-length Tat was PCR amplified with Pfu polymerase (Life Technology) using the following oligonucleotides: 5'-AGTCAA GCTTACCATGGAGCCAGTAGAT CCTAG-3' and 5'-AGTCGGATCCGCTTCCTTCG GGCCTGTCGGGT-3' (for Tat-EGFP); 5'-ACTG AAGCTTTAATGGAGCCAGTAGATCCTAGACT AG-3' and 5'-A CTGGGATCCCTATTCCTTCGGG CCTGTCGG-3' (for EGFP-Tat). The amplified PCR products were digested with BamHI and HindIII and inserted into the EGFP-N1 or EGFP-C1 vector (Clontech). To construct plasmid coding for the basic domain of Tat-protein fused with EGFP (EGFP$\mathrm{Tat}^{\mathrm{bd}}$ ), the oligonucleotides 5'-AGCTAGGAAGAA GCGGAGACAG CGACGAAGAG-3' and 5'-GAT CCTCTTCGTCGCTGTCTCCGCTTCTTCCT-3' were annealed and ligated into a HindIII- and Bam HI-digested pEGFP-C1 vector (Clontech).

HeLa cells were grown in Dulbecco's modified Eagle's medium supplemented with L-glutamine, $8 \%$ fetal calf serum (HyClone) and antibiotic/antimycotic solution (Gibco). Cellular transfection was performed using TurboFect reagent (Life Technology) according to the manufacturer's instructions. Images of at least 50 living cells expressing fusion proteins were acquired in two different experiments using an LSM510 confocal laser scanning microscope (Carl Zeiss). To evaluate the nuclear and nucleolar accumulation efficiency, the mean fluorescence intensity in the nucleolus, in the nucleoplasm and in the cytoplasm was measured using Image 2 software. The ratio of nucleolar EGFP concentration to nucleoplas- mic EGFP concentration has previously been referred to as the NoLS activity [12]. The ratio of cytoplasmic EGFP concentration to nucleoplasmic EGFP concentration is referred to as NLS activity.

\section{Results and Discussion}

In order to characterize the accumulation of Tat protein in the nucleus and nucleolus, plasmids encoding Tat protein fused with EGFP (Tat-EGFP and EGFPTat) were constructed. The basic domain of Tat protein (RKKRRQRRR) contains both NLS [4, 13-17] and NoLS $[4,17]$. We constructed a plasmid coding for the basic domain of Tat protein fused to EGFP (EGFP-Tat ${ }^{\mathrm{bd}}$ ). EGFP, a biologically inert protein weakly interacting with cell structures was used as a control. The plasmids encoding these proteins and the marker nucleolar protein (B23-TagRFP) were transfected into HeLa cells, and the protein localization was analyzed in vivo using a confocal microscope.

The images of cells expressing the chimeric proteins are shown in Figure 1. EGFP was distributed throughout the cell, with the exception of the nucleoli, in which the EGFP concentration was reduced. Tat-EGFP and EGFP-Tat were accumulated in the nuclei and the nucleoli; their concentration in cytoplasm was significantly reduced. EGFP-Tat ${ }^{\text {bd }}$ was preferentially accumulated in the nucleoli as compared to the full-length Tat protein.

To estimate the accumulation, we measured the EGFP fluorescence levels in the cytoplasm, nucleoplasm and nucleoli, and determined the efficiency of accumulation of the studied proteins in the nucleoplasm (NLS activity) and the nucleolus (NoLS activity). A quantitative analysis indicates that both TatEGFP and EGFP-Tat were more intensively accumulated in the nucleoplasm as compared to EGFPTat $^{\text {bd }}$ (Fig. 2, A). In the case of nucleolar accumulation, the situation was reverse: EGFP-Tat ${ }^{\text {bd }}$ was accumulated in the nucleoli stronger, compared with the full-length Tat protein (Fig. 2, B).

These differences may be connected with the mechanism of nuclear and nucleolar accumulation. It was described that Tat protein accumulates in the nucleus through the interactions with nuclear components, possibly with RNA [18]. This interaction may require the 


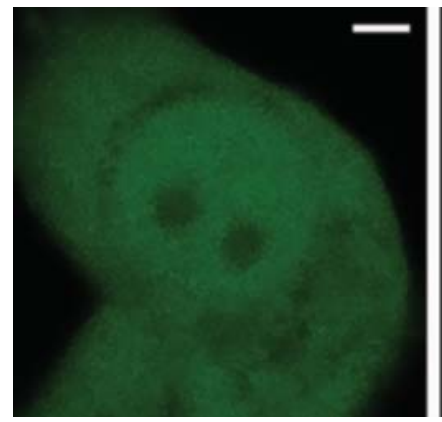

EGFP

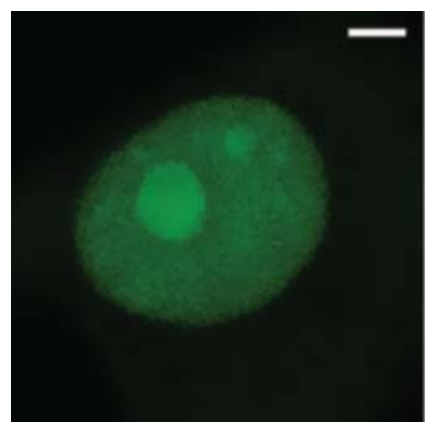

Tat-EGFP

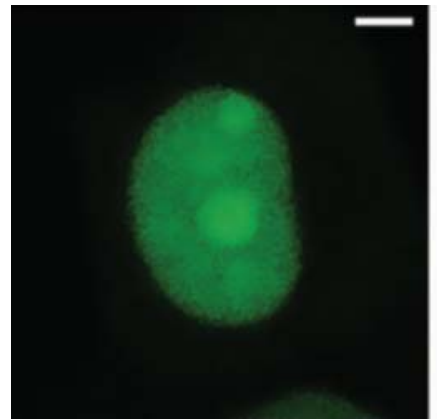

EGFP

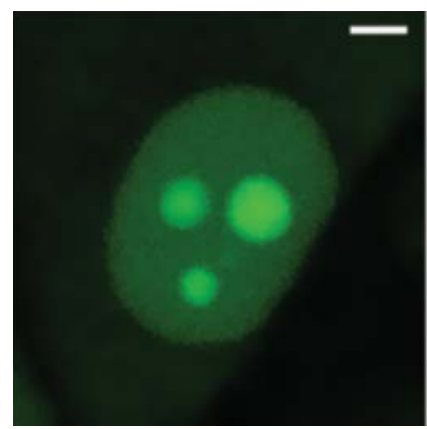

EGFP-Tat ${ }^{\text {bd }}$

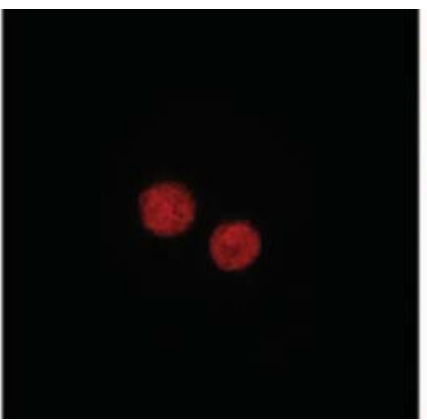

B23-TagRFP

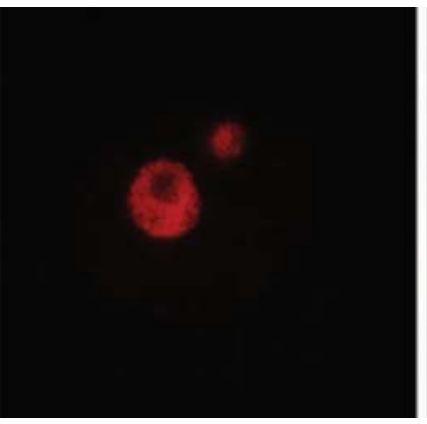

B23-TagRFP

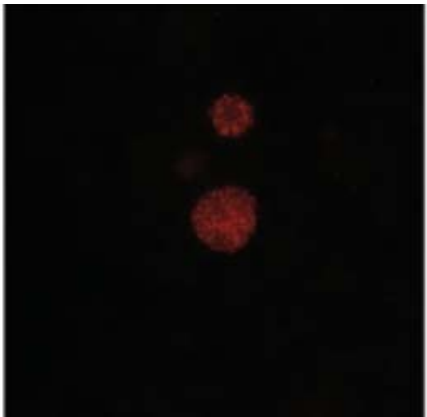

B23-TagRFP

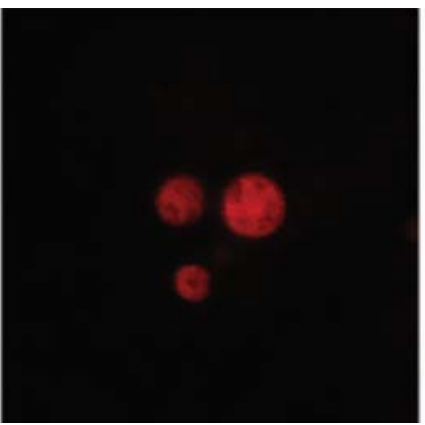

B23-TagRFP

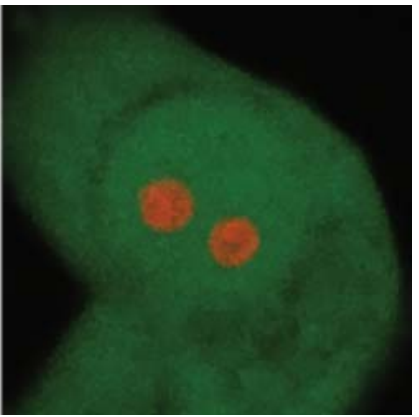

Merge

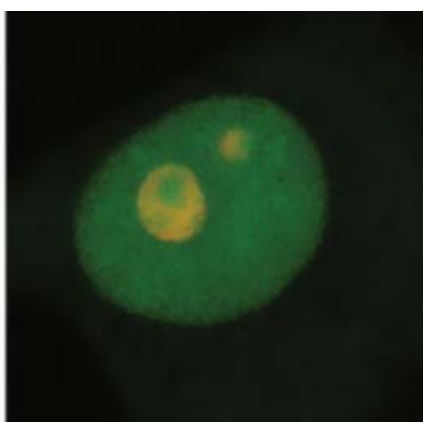

Merge

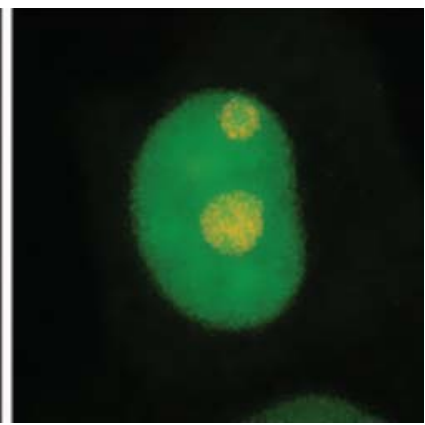

Merge

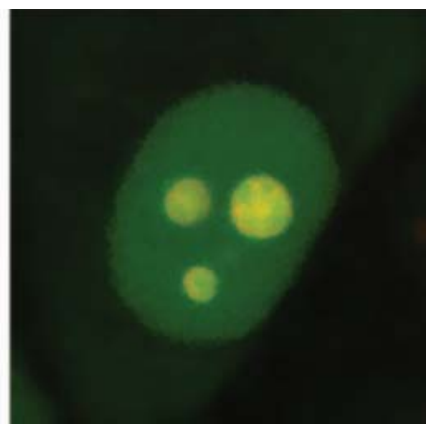

Merge

Fig. 1. Localization of chimeric proteins (green) and nucleolar protein B23-TagRFP (red) in living HeLa cells. Bars $-5 \mu \mathrm{m}$. The distributions of coexpressed proteins were analized in living HaLa cells using confocal microscope. B23-TagRFP was used as a marker of nucleolus 

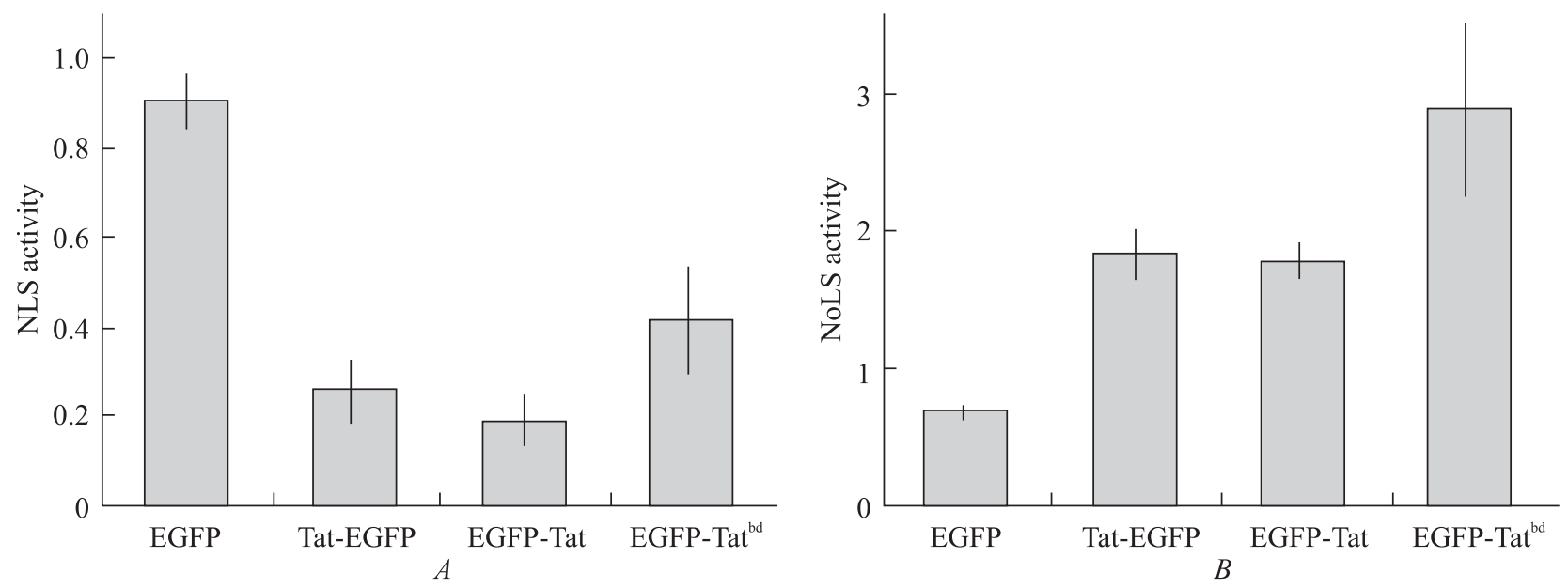

Fig. 2. Efficiency of nuclear $(A)$ and nucleolar $(B)$ accumulation of chimeric proteins (mean $\pm S D$ ). The ratio of cytoplasmic EGFP concentration to nucleoplasmic EGFP concentration characterized efficiency of removal of protein from the cytoplasm and is referred to as NLS activity. The ratio of nucleolar EGFP concentration to nucleoplasmic EGFP concentration estimates the efficiency of nucleolar accumulation and is referred to as NoLS activity

presence of the flanking sequences or the particular three-dimensional configuration of the basic domain that can occur only in the full-length protein.

Using the NoLS of Tat protein fused with EGFP, we have previously demonstrated that the electrostatic interaction of NoLS with the nucleolar components may lead to the nucleolar accumulation [19]. The charge of the basic domain can be partially compensated by the nearest amino acid residues within the full-length protein, or the basic domain can be less accessible to interact with components of the nucleoli.

Thus, the data obtained using the protein fragments might be different from those obtained by the analysis of full-length proteins. One cannot exclude that the mechanisms of nuclear or/and nucleolar accumulation might be also different in these two experimental systems, and some data indicate that the latter situation is quite possible. For example, it was described that nucleolar accumulation of the Tat protein may be due to its interaction with the nucleolar protein B23 [15], but NoLS of the Tat protein rather interacts with the nucleolar RNAs [19]. The reinvestigation of nuclear and nucleolar accumulation of proteins using full-length proteins might lead to principally different results and reveal novel molecular mechanisms.

\section{Acknowledgements}

The following reagent was obtained through the NIH AIDS Reagent Program, Division of AIDS, NIAID, NIH: (pGST-Tat 1 86R) from Dr. Andrew Rice.

\section{Funding}

This work was supported by the Russian Science Foundation (project 14-15-00199).

\section{REFERENCES}

1. Van Lint C, Bouchat S, Marcello A. HIV-1 transcription and latency: an update. Retrovirology. 2013;10:67.

2. Mbonye U, Karn J. Transcriptional control of HIV latency: cellular signaling pathways, epigenetics, happenstance and the hope for a cure. Virology. 2014;454-455:328-39.

3. Romani B, Engelbrecht S, Glashoff RH. Functions of Tat: the versatile protein of human immunodeficiency virus type 1. J Gen Virol. 2010;91(Pt 1):1-12.

4. Kuppuswamy M, Subramanian T, Srinivasan A, Chinnadurai $G$. Multiple functional domains of Tat, the trans-activator of HIV-1, defined by mutational analysis. Nucleic Acids Res. 1989;17(9):3551-61.

5. Ruben S, Perkins A, Purcell R, Joung K, Sia R, Burghoff R, Haseltine WA, Rosen CA. Structural and functional characterization of human immunodeficiency virus tat protein. $J$ Virol. 1989;63(1):1-8.

6. Coiras M, Camafeita E, Ureña T, López JA, Caballero F, Fernández B, López-Huertas MR, Pérez-Olmeda M, Alcamí $J$. Modifications in the human $\mathrm{T}$ cell proteome induced by 
intracellular HIV-1 Tat protein expression. Proteomics. 2006; 6(Suppl 1):S63-73.

7. Stauber RH, Pavlakis GN. Intracellular trafficking and interactions of the HIV-1 Tat protein. Virology. 1998;252(1): 126-36.

8. Dundr $M$. Nuclear bodies: multifunctional companions of the genome. Curr Opin Cell Biol. 2012;24(3):415-22.

9. Lange A, Mills RE, Lange CJ, Stewart M, Devine SE, Corbett $A H$. Classical nuclear localization signals: definition, function, and interaction with importin alpha. J Biol Chem. 2007;282(8):5101-5.

10. Emmott E, Hiscox JA. Nucleolar targeting: the hub of the matter. EMBO Rep. 2009;10(3):231-8.

11. Rhim H, Echetebu CO, Herrmann CH, Rice AP. Wild-type and mutant HIV-1 and HIV-2 Tat proteins expressed in Escherichia coli as fusions with glutathione S-transferase. J Acquir Immune Defic Syndr. 1994;7(11):1116-21.

12. Musinova YR, Lisitsyna OM, Golyshev SA, Tuzhikov AI, Polyakov VY, Sheval EV. Nucleolar localization/retention signal is responsible for transient accumulation of histone $\mathrm{H} 2 \mathrm{~B}$ in the nucleolus through electrostatic interactions. Biochim Biophys Acta. 2011;1813(1):27-38.

13. Hauber J, Malim MH, Cullen BR. Mutational analysis of the conserved basic domain of human immunodeficiency virus tat protein. J Virol. 1989;63(3):1181-7.

14. Meredith LW, Sivakumaran H, Major L, Suhrbier A, Harrich $D$. Potent inhibition of HIV-1 replication by a Tat mutant. PLoS One. 2009;4(11):e7769.

15. Li YP. Protein B23 is an important human factor for the nucleolar localization of the human immunodeficiency virus protein Tat. J Virol. 1997;71(5):4098-102.

16. Orsini MJ, Debouck CM. Inhibition of human immunodeficiency virus type 1 and type 2 Tat function by transdominant Tat protein localized to both the nucleus and cytoplasm. J Virol. 1996;70(11):8055-63.

17. Pearson L, Garcia J, Wu F, Modesti N, Nelson J, Gaynor R. $A$ transdominant tat mutant that inhibits tat-induced gene expression from the human immunodeficiency virus long terminal repeat. Proc Natl Acad Sci U S A. 1990;87(13):5079-83.

18. Cardarelli F, Serresi M, Albanese A, Bizzarri R, Beltram F. Quantitative analysis of Tat peptide binding to import carriers reveals unconventional nuclear transport properties. $J$ Biol Chem. 2011;286(14):12292-9.

19. Musinova YR, Kananykhina EY, Potashnikova DM, Lisitsyna OM, Sheval EV. A charge-dependent mechanism is responsible for the dynamic accumulation of proteins inside nucleoli. Biochim Biophys Acta. 2015;1853(1):101-10.
Накопичення в ядрі і полісом основного домену ВІЛ-1 Таt білка відрізняється від накопичення повнорозмірного білка

Я. Р. Мусинова, Є. В. Шеваль

Мета. При вивченні механізмів накопичення білків в ядрі і полісом часто використовують фрагменти білка, що кодують сигнали ядерної (NLS) i/або ядерцевої (NoLS) локалізації, які зливають 3 маркерними білками. Проте механізми накопичення повнорозмірних білків можуть бути іншими. Методи. У цій роботі ми порівняли накопичення в ядрі і полісом BIЛ-1 Tat білка і основного домену цього білка, що містить NLS i NoLS. Результати. Показано, що накопичення основного домену Тат білка в ядрі і полісом відрізняється від накопичення цілих білків (фрагмент білка гірше, ніж цілий білок накопичується в ядрі, але краще в полісом). Висновки. Видається ймовірним, що молекулярні механізми накопичення в ядрі і полісом повнорозмірного Тат білка можуть відрізнятися від механізму, описаного з використанням фрагментів білка.

Кл юч о в і сл о в а: ядро, ядрерце, NLS, NoLS, HIV-1 Tat.

\section{Накопление в ядре и ядрышке основного домена HIV-1 Tat белка отличается от накопления полноразмерного белка}

\section{Я. Р. Мусинова, Е. В. Шеваль}

Цель. При изучении механизмов накопления белков в ядре и ядрышке часто используют участки белка, кодирующие сигналы ядерной (NLS) и/или ядрышковой (NoLS) локализации, которые сливают с маркерными белками. Однако механизмы накопления полноразмерных белков могут быть другими. Методы. В настоящей работе мы сравнили накопление в ядре и ядрышке HIV-1 Tat белка и основного домена этого белка, содержащего NLS и NoLS. Результаты. Показано, что накопление основного домена Tat белка в ядре и ядрышке отличается от накопления целых белков (фрагмент белка хуже, чем целый белок накапливается в ядре, но лучше в ядрышке). Выводы. Представляется вероятным, что молекулярные механизмы накопления в ядре и ядрышке полноразмерного Tat белка могут отличаться от механизма, описанного с использованием фрагментов белка.

Ключевы е сл о а: ядро, ядрышко, NLS, NoLS, HIV-1 Tat. Received 08.01.2015 